\title{
TOXIC ACTION OF ELECTROLYTES UPON FISHES
}

\author{
BY LOUIS KAHLENBERG AND HCGO F. MEHL,
}

Several investigations on the toxis action of various aqueous solutions upon plants have been made in this laboratory. It was thought desirable to carry out similar researches with animals; and, after a few preliminary experiments, fishes were found to be subjects upon which experiments of the kind contemplated could readily be performed.

The chief aim of this investigation is to compare various dilute aqueous solutions that conduct electricity by observing how long fishes can live in them. The following is an outline of the method of experimentation. A fish of small size - see definite data in the tables below - was placed in $500 \mathrm{cc}$ of the solution to be tested, which was contained in a porcelain casserole of about I liter capacity, and the time required to produce death was carefully noted. Control experiments were conducted in each case, using distilled water, for of course a fish will die in so small an amount of water when the limited amount of dissolved oxygen that it contains has been largely consumed. In noting the time necessary for the fish to succumb, it was at first thought best to pronounce the animal dead when all motion had ceased. This was found to be impracticable, however, for owing to slight muscular contraction that in some cases continued for an appreciable time, the time at which death occurred would not be sufficiently sharply defined. When a fish is placed in a toxic solution, the phenomena observed vary somewhat with the nature of the solution; generally, however, the fish moves about in a lively manner, which movements may in sonve cases culminate in attempts to jump out of the dish. ${ }^{x}$ After a time the

1 To prevent the fish from getting out of the dish, a glass plate was placed over the casserole in such cases. This plate did not tit the dish closely, however, and so did not entirely prevent the circulation of air beneath it. 
movements of the fish become less pronounced; it finally loses control of its motions, and turns over on its back. The latter phenomena occurs suddenly, and though the fish generally continues to move somewhat after its ventral side has turned up, it never again regains control of its motions and the latter soon cease entirely. Because the time at which the fish turns over on its back is so well defined, it was taken in each case as the time at which death occurred. In the tables given below, then, the figures in the column headed "time required to produce death" really indicate the time that elapsed from the instant that the fish was placed in the solution to the monent when its ventral side turned upwards. The post-mortem appearances of the specimens killed in various solutions are of interest and will consequently be given below in each case. After death had occurred, the length and also the weight of each fish was ascertained, the former to about I $\mathrm{mm}$ and the latter to within o.or gram. These data are included in the tables that follow. The experiments were conducted at room temperature, between $18^{\circ}$ and $20^{\circ} \mathrm{C}$.

- Three different species of fish were used in the experiments, viz. : - rock-bass (amblo-plites mpestris), the common shiner, also called dace or redfin (n.megalop refinesque), and brook-tront (salvelinus fontinalis). A few tests were also made with the ordinary yellow perch (perca flavescens). All the specimens except the brook-tront were caught in Lake Mendota ${ }^{x}$ near the shore. The investigations were made during the months of October and November, and when in the latter month cold weather came and the fishes songht deeper water, it scemed at first that no further tests could be made at that time. However, through the kindness of Mr. James Nevin, to whom we feel especially indebted, some very fine specimens of brook-tront were obtained from the Wisconsin State Fish Hatcheries, located near Madison. The fishes were of as nearly the same weight and length as could very well be obtained in any quantity, the extreme variations (leaving the percli out of consideration) being 0.5 to

\footnotetext{
${ }^{1}$ At Madison, Wisconsin.
} 
5 grams, and 25 to IO2 mm. They were all of the spring's hatch and were from four to six months old. During the night they were kept in a large perforated pail suspended in the lake, and during the day when they were wanted for experimentation, they were kept near at hand in an aquarium through which coursed a continuous stream of fresh lake water. The vitality of the fishes was thus impaired as little as possible during the time they were held in captivity. Moreover, the experiments were conducted as soon as possible after the fish were caught, usually on the same day. As the fishes are all of well known species, a detailed description of them may here be omitted.

The experimental results are given in Tables I. to IV., which are self-explanatory. The strengths of the solutions are indicated in eacli case in terms of equivalent normal solutions.

Dilute solutions of hydrochloric, nitric, and sulphuric acids, were tested with rock-bass. The results obtained are presented in Table I.

TABLE I

Rock-bass (amblo-plites mpestris)

\begin{tabular}{|c|c|c|c|c|c|c|c|c|c|c|}
\hline \multicolumn{3}{|c|}{ Length } & \multicolumn{2}{|c|}{ Weight } & \multicolumn{2}{|c|}{ Solutions } & \multicolumn{4}{|c|}{$\begin{array}{l}\text { Time required to } \\
\text { produce deatl }\end{array}$} \\
\hline \multicolumn{3}{|c|}{$32 \mathrm{~mm}$} & $0.55 \mathrm{~g}$ & ram & $n / 100$ & $\mathrm{HCl}$ & \multicolumn{4}{|c|}{6 minl } \\
\hline & $5^{\mathrm{I}}$ & $"$ & 3.00 & " & & & 7 & “" & $30 \mathrm{~s}$ & $\mathrm{sec}$ \\
\hline & 25 & $" 6$ & 0.85 & " & “ & $" ،$ & 6 & & & \\
\hline Aver. & 36 & $"$ " & I. 46 & $"$ & & . & 6 & & $3^{\circ}$ & “" \\
\hline & 32 & $" ،$ & 1.30 & "s & $n / 100$ & $\mathrm{HNO}_{3}$ & 6 & $"$ & 30 & " \\
\hline & 45 & " & 2.30 & $" 6$ & & " & 7 & s' & & \\
\hline & 5I & $" 6$ & 2.30 & $" 6$ & "“ & & 7 & “ & 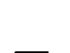 & \\
\hline Aver: & 43 & $"$ " & 1.96 & $"$ " & & & 6 & “ & & $"$ \\
\hline & 32 & $\because$ & 0.55 & $" c$ & $n / 100$ & $\mathrm{H}_{2} \mathrm{SO}_{4}$ & 7 & "، & & \\
\hline & 32 & "r & 0.52 & "6 & " & "، & 6 & 16 & & \\
\hline & 45 & "r & 1.94 & "r & “" & $" ،$ & 9 & “" & & \\
\hline Aver. & 36 & ، & 1.00 & " & & & 7 & " & 20 & $" r$ \\
\hline
\end{tabular}




\begin{tabular}{|c|c|c|c|c|c|c|c|c|c|}
\hline & engtl & & Wei & & Solutions & $\begin{array}{l}\text { Time } \\
\text { prod }\end{array}$ & $\begin{array}{l}\text { req } \\
\text { unce }\end{array}$ & $\begin{array}{l}\text { ired } \\
\text { deat }\end{array}$ & \\
\hline Aver. & 321 & & I. 47 & ram & $n / 250 \mathrm{HCl}$ & & $\min$ & & \\
\hline & $3^{2}$ & "6 & I. 32 & $"$ & & 8 & $"$ & 30 & $\sec$ \\
\hline & $3^{2}$ & ‘، & I.24 & "s & " & 9 & " & - & \\
\hline Aver. & $3^{2}$ & " & I.34 & " & & 8 & $"$ & $5^{\circ}$ & “ \\
\hline & 32 & “ & 1.64 & “ & $n / 250 \mathrm{HNO}_{3}$ & 9 & “ & 30 & “ \\
\hline & $3^{2}$ & $\because$ & 1.60 & " & & 9 & $"$ & & \\
\hline & $3^{2}$ & " & I.34 & “" & " & 8 & " & 30 & “" \\
\hline Aver. & 32 & " & I. 53 & “" & & 9 & $" r$ & & \\
\hline & $3^{2}$ & $"$ " & I. 14 & “ & $n / 25 \mathrm{O} \mathrm{H}_{2} \mathrm{SO}_{4}$ & 9 & $" ،$ & 30 & “ \\
\hline & 32 & “ & $\mathrm{I} .24$ & ، & $\because 68$ & 9 & $\because$ & 30 & " \\
\hline & 32 & $"$ & 1.40 & " & ' 6 & IO & "r & 30 & $"$ \\
\hline Aver. & 32 & $\because$ & I. 26 & ، & & 9 & " & 50 & "، \\
\hline & $3^{8}$ & $" ،$ & I.I 7 & " & $n / 500 \mathrm{HCl}$ & I 2 & “ & & \\
\hline & $3^{8}$ & '، & I. 55 & $\because$ & $\because 6$ & I I & $،$ & & \\
\hline & $3^{8}$ & “" & 1.20 & $\because$ & “" & I I & $" r$ & & \\
\hline Aver. & 38 & "، & 1.27 & “ & 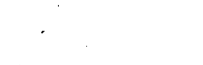 & $\overline{\text { II }}$ & $\because$ & $\overline{20}$ & ‘ \\
\hline & 32 & " & I. I 5 & “ & $n / 500 \mathrm{HNO}_{3}$ & I 2 & “ & & \\
\hline & $3^{8}$ & $"$ & I. 45 & ، & " " & I 2 & “ & & \\
\hline & 32 & $"$ & I. 25 & “" & " & I 3 & "، & & \\
\hline Aver. & 34 & $" 6$ & I. 28 & “ & & 12 & " & 20 & 6 \\
\hline & 38 & ، & 1.32 & “ & $n / 500 \mathrm{H}_{2} \mathrm{SO}_{4}$ & 14 & ، & 30 & ، \\
\hline & $3^{8}$ & " & 1.27 & $"$ & “" & I 3 & " & & \\
\hline & $3^{8}$ & $\because$ & 0.85 & “" & “" & I 4 & ‘ & & \\
\hline Aver. & 38 & "1 & I. I 4 & $\because$ & & I 3 & $“$ & 50 & $"$ \\
\hline & 32 & “ & I. 45 & “ & $n / 1000 \mathrm{HCl}$ & I 8 & " & 30 & $،$ \\
\hline & 45 & “ & 2.10 & “ & " & 20 & “" & & \\
\hline & 32 & $"$ & I. 55 & “" & “ & $2 \mathrm{I}$ & $" r$ & & \\
\hline Arer. & 36 & ' & 1.70 & $"$ & & 19 & " & 50 & "، \\
\hline
\end{tabular}




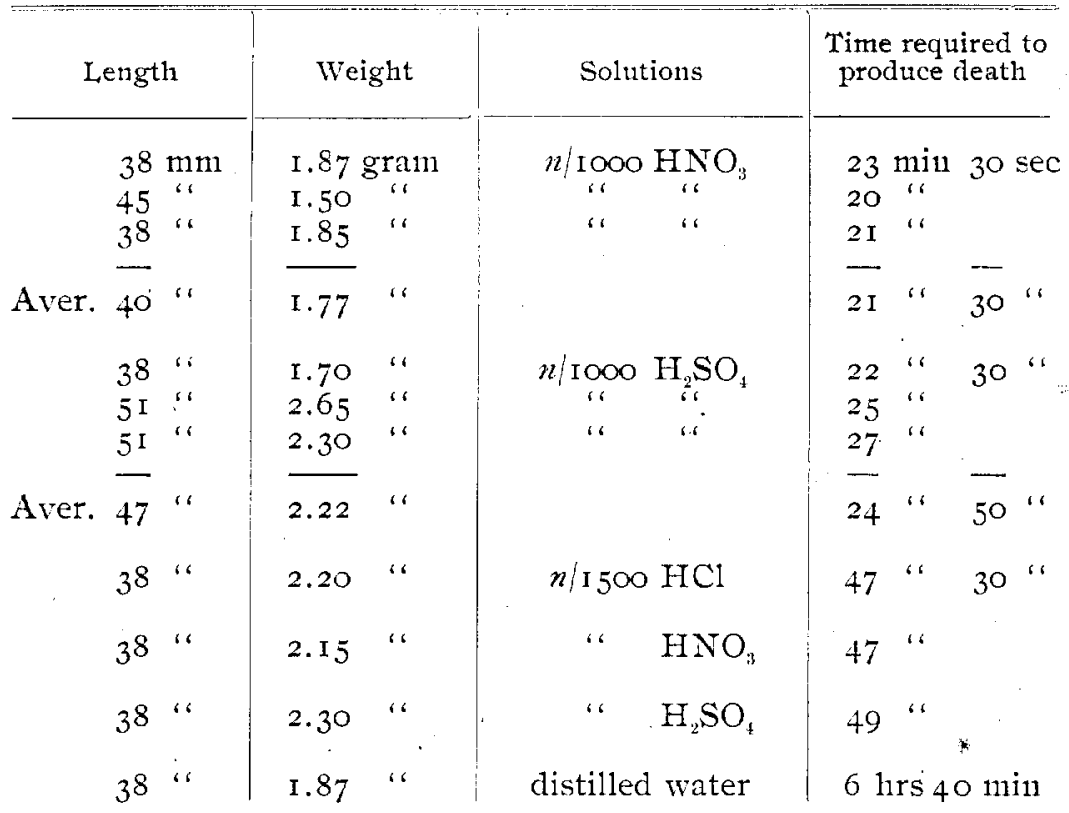

It will be observed that $n /$ Ioo is the strongest solution of the mineral acids given in the table. In a normal solution of any of these acids or of caustic potash a fish does not survive longer than five to ten seconds, while even in a $n /$ io solution, death occurs in less than a minute, so that these relatively strong solutions could not be used to obtain accurate measurements. Hydrochloric, nitric, and sulphuric acid solutions stronger than $n / 500$ cause blood to ooze from the gills of the fish. The more concentrated the solution, the more pronounced the hemorrhage. The acid evidently destroys the deiicate protective tissues and lays the blood vessels bare. It is interesting to notice that solutions that cause no hemorrhage also have but a very faint sour taste, the limit at which the sense of taste can still experience sourness being at about $u / 800$. The gills change from their beautiful maroon to a dark brown, and finally to a dirty gray color, owing to coagulation of blood. There can be little doubt that death occurs because of the destruction of the breathing apparatus of the animal. The general appearance of the fish after death is changed but little. Some of the mucts 
has been removed from the scales; the month is open; the color remains about the same.

An inspection of the results shows that a slight difference in the weight of a fish makes but little difference in the time that it is able to survive in the solution; this is also shown by the results of the other tables given below. It is, of course, not to be expected that two fishes of the same species will have exactly the same vitality or resisting power simply because they hap"pent to be of the same length and weight ; individuality does come in as a factor in nearly all biological specimens to a certain extent.

The results in Table I. indicate that $\mathrm{HCl}$ and $\mathrm{HNO}_{3}$ have nearly the same destructive effect, the toxic action apparently being a little stronger in the case of the former acid. Sulphuric acid is a little less virulent in its action than the other two acids. This appears even in the $n / I 500$ solution, the weakest one tested. It is well to bear in mind that the toxic action of these acids upon rock-bass is in about the same order as it is upon bacteria and higher plants. The nature of the action of these three acids was, furthermore, alike as far as was ascertained from the behavior of the fishes in the solutions and from the post-mortem exanninations. The action of the acids must therefore be ascribed to that which they have in common, namely their replaceable hydrogen. As far as the results in Table I. are concerned, it may of course be held with propriety that they harmonize with the theory of electrolytic dissociation, namely, that it is the hydrogen ions that kill the fish. The character of these particular results would hardly warrant an attempt to make a sharp quantitative comparison between the toxic effect of these acids and 'their degree of hydrogen dissociation. Unfortunately, a number of solutions of acid sodium salts lave not yet been tested with fishes, as they have with plants ${ }^{x}$ and by means of the sense of taste. ${ }^{2}$ It is contemplated to make such tests when it is again possible to obtain the fishes necessary for the work. It is extremely likely that such tests will show (as they have done in the case of plants and taste) that the assumption that the observed toxic effect is caused by so-called hydrogen ions is not tenable.

\footnotetext{
${ }^{1}$ Kahlenberg and Anstin. Jour. Phys. Chenn. 4, 553 (1900).

2Kahlenberg. Ibid. 4, 33, 533 (I900).
} 
Table II. gives the results obtained with shiners. It will be observed that hydrochloric, nitric and sulphuric acids were tested with this species, and that in addition, cattstic potash, common salt, and the nitrate and sulphate of silver were used.

TABLE II

Shiner (n.megalop rafinesque)

\begin{tabular}{|c|c|c|c|c|c|c|c|c|c|}
\hline \multicolumn{3}{|c|}{ Length } & \multicolumn{2}{|c|}{ Weight } & Solution & \multicolumn{4}{|c|}{$\begin{array}{l}\text { Tine required to } \\
\text { produce death }\end{array}$} \\
\hline \multicolumn{3}{|c|}{ 5I $\mathrm{mm}$} & \multicolumn{2}{|c|}{1.52 gram } & \multirow{2}{*}{$\begin{array}{l}n / 100 \mathrm{HCl} \\
n / 100 \mathrm{HNO}_{3}\end{array}$} & \multicolumn{4}{|c|}{$20 \mathrm{sec}$} \\
\hline & $3^{8}$ & " & I. IO & “ & & I 5 & " & & \\
\hline & & “ & 0.50 & " & $n / \mathrm{IOO} \mathrm{H}_{2} \mathrm{SO}_{4}$ & 20 & & & \\
\hline & & $\because$ & 1.95 & “ & $n / 250 \mathrm{HCl}$ & 45 & & & \\
\hline & & “ & 1.95 & “ & "6 & 45 & “ & & \\
\hline & 64 & $" ،$ & 2.35 & ، & " & I & min & & sec \\
\hline Aver. & 55 & “ & 2.08 & " & & & & 55 & " \\
\hline & 38 & ' & I. 55 & $“$ & $n / 25 \circ \mathrm{HNO}_{3}$ & I & & 30 & $"$ \\
\hline & $5 I$ & " & J. 55 & $" r$ & $\because 60$ & I & $" \because$ & 20 & $" 6$ \\
\hline & 45 & $\cdot "$ & I. I 5 & " & "6 & I & $" “$ & 20 & "“ \\
\hline Aver. & 33 & ' & I. 38 & $"$ & & I & $"$ & 23 & " \\
\hline & 38 & $"$ & 0.85 & “ & $n / 25 \mathrm{OH}_{2} \mathrm{SO}_{4}$ & 2 & & & \\
\hline & 38 & $"$ & 1.00 & 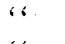 & " & 2 & " & I 5 & \\
\hline & $5 \mathrm{I}$ & $"$ & 0.95 & $"$ & "6 & 2 & $"$ " & IO & "، \\
\hline Aver. & 42 & " & 0.93 & “ & & 2 & ، & 8 & ، \\
\hline & 38 & " & 0.75 & “ & $n / 500 \mathrm{HCl}$ & 3 & ' & & \\
\hline & 38 & “ & 0.70 & " & "i & 2 & $\because$ & & \\
\hline & $3^{8}$ & $" ،$ & 0.70 & “ & “ & 2 & “ & & \\
\hline Aver. & $\overline{38}$ & " & $\overline{0.72}$ & $"$ & & 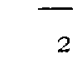 & “ & $\overline{20}$ & “ \\
\hline & 38 & " & 0.75 & $\because$ & $n / 500 \mathrm{HNO}_{3}$ & 2 & " & & \\
\hline & 38 & “ & 0.85 & “ & " & 2 & “ & I 5 & " \\
\hline & $3^{8}$ & “' & I.05 & “ & “ & 3 & “ & 5 & “ \\
\hline Aver. & 38 & " & 0.88 & $\because$ & & 2 & ، & 26 & $"$ \\
\hline
\end{tabular}




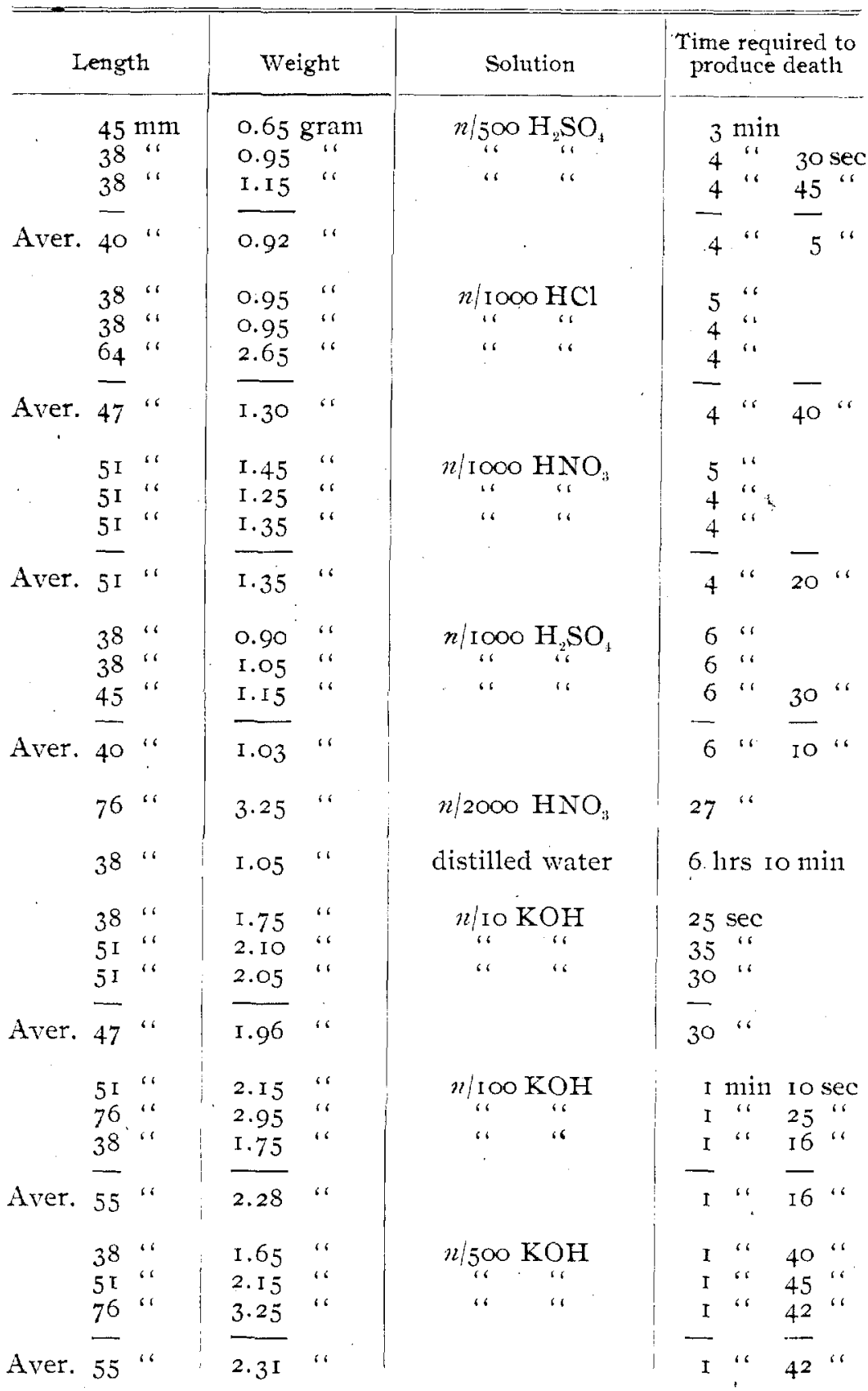




\begin{tabular}{|c|c|c|c|c|c|c|c|c|c|}
\hline & ength & & Wei & & Solution & $\begin{array}{l}\text { Time } \\
\text { prod }\end{array}$ & $\begin{array}{l}\text { requ } \\
\text { luce }\end{array}$ & $\begin{array}{l}\text { ired to } \\
\text { death }\end{array}$ & \\
\hline & & min1 & 2.058 & ram & $n / 1000 \mathrm{KOH}$ & 2 & $\min _{\|}$ & Io sec & ec \\
\hline & & $"$ & $\begin{array}{l}2.55 \\
1.95\end{array}$ & ، & " & $\begin{array}{l}2 \\
2\end{array}$ & 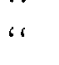 & $\begin{array}{l}30 ", \\
\text { I } 5 "\end{array}$ & \\
\hline Aver. & $\overline{55}$ & “ & $\overline{2.18}$ & $"$ & & - & "r & $\overline{18}$ " & 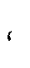 \\
\hline & 38 & “ & $\mathrm{I} .45$ & “ & $n / 2000 \mathrm{KOH}$ & 4 & " & $30 "$ & “ ، \\
\hline & $5^{1}$ & " & I. 85 & ‘ & $n / \mathrm{I} \mathrm{NaCl}$ & I & “ & Io" & ، \\
\hline & 38 & “ & 1.35 & “ & $\because 4$ & I & “" & $25^{\prime}$ & “" \\
\hline & $3^{8}$ & $"$ & I. 45 & "“ & $\therefore$ & I & $"$ & $25^{\prime}$ & “" \\
\hline Aver. & 42 & " & I. 55 & ، & & I & " & $20^{\prime \prime}$ & “" \\
\hline & 38 & " & I. 65 & " & $n / 2 \mathrm{NaCl}$ & 3 & “ & $40^{\prime \prime}$ & “ \\
\hline & $5 \mathrm{I}$ & “ & 2.10 & " & " & 4 & “" & & \\
\hline & 38 & $"$ & 1.55 & “ & " & 3 & "“ & $45^{\prime}$ & “" \\
\hline Aver. & 42 & " & I. 76 & " & & 3 & “ & $50^{\prime}$ & ، \\
\hline & 76 & “ & 3.05 & $" ،$ & $n / 4 \mathrm{NaCl}$ & 40 & “ & & \\
\hline & 64 & " & 2.45 & “ & " & 35 & "، & + & \\
\hline Aver. & 70 & " & 2.75 & " & & 37 & “ & 30 & " \\
\hline & 25 & “ & 0.60 & $"$ & $n / 10000 \mathrm{AgNO}_{3}$ & 2 & “ & $50^{\circ}$ & " \\
\hline & 38 & “ & I. 45 & "، & " & 2 & “" & 45 & “ \\
\hline & 25 & "، & 0.70 & $"$ & . & 2 & $"$ & 50 & “‘ \\
\hline Aver. & 29 & “ & 0.92 & ، & & 2 & “ & $47^{\prime}$ & " \\
\hline & 64 & “ & 2.55 & “ & $n / \mathrm{IO} 00 \mathrm{O} \mathrm{Ag}_{2} \mathrm{SO}_{4}$ & 2 & “ & 55 & “ \\
\hline & 32 & " & 1.25 & $" ،$ & " 6 & 2 & “ & 45 & “" \\
\hline & 32 & “" & I. I 5 & "، & & 2 & " & $\underline{50}^{\circ}$ & $"$ \\
\hline Aver. & 53 & " & I. 65 &. & & 2 & ‘ & $50^{\prime}$ & " \\
\hline & 76 & “ & 2.95 & 16 & $n / 20000 \mathrm{AgNO}_{3}$ & 4 & “ & 50 & ، \\
\hline & 38 & “ & 1.45 & “ & 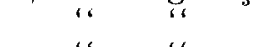 & 4 & " & 25 & “ \\
\hline & 38 & "، & I. 75 & " & " & 4 & " & 50 & “" \\
\hline Aver. & $5 \mathrm{I}$ & “ & 2.05 & " & & 4 & & $4 \mathrm{I}$ & \\
\hline
\end{tabular}




\begin{tabular}{|c|c|c|c|c|c|c|c|c|c|}
\hline \multicolumn{3}{|c|}{ Length } & \multicolumn{2}{|c|}{ Weight } & Solution & \multicolumn{4}{|c|}{$\begin{array}{l}\text { Time required to } \\
\text { produce death }\end{array}$} \\
\hline & \multicolumn{2}{|c|}{$38 \mathrm{~mm}$} & \multicolumn{2}{|c|}{ I.55 granl } & \multirow{2}{*}{$\begin{array}{c}n / 20000 \mathrm{Ag}_{2} \mathrm{SO}_{4} \\
، \\
" ،\end{array}$} & \multicolumn{2}{|c|}{$4 \mathrm{~min}$} & \multicolumn{2}{|c|}{$\begin{array}{l}50 \mathrm{sec} \\
25\end{array}$} \\
\hline & 38 & ، & $\mathrm{I} .45$ & " & & 5 & " & 25 & ، \\
\hline Aver. & $\overrightarrow{3^{8}}$ & $\because$ & $\overline{1.53}$ & 6 & · & 4 & “" & $\overline{53}$ & 16 \\
\hline & $3^{8}$ & " & 1.70 & $"$ & $n / 50000 \mathrm{AgNO}_{3}$ & 5 & " & 20 & ، \\
\hline & 38 & $\because$ & 1.75 & $"$ & $\because \quad \because$ & 5 & ‘ & 20 & “" \\
\hline & 38 & $\because$ & 1.65 & " & " & 6 & $"$ & 30 & “ \\
\hline Aver. & $3^{8}$ & $"$ & I. 70 & $"$ & & 5 & $"$ & 43 & " \\
\hline & 32 & “ & I. I 5 & $\because$ & $n / 50000 \mathrm{Ag}_{2} \mathrm{SO}_{4}$ & 5 & " & I 5 & ، \\
\hline & $5^{I}$ & 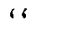 & 2.10 & $\because$ & 164 & 5 & "، & 45 & “ \\
\hline & $5 \mathrm{I}$ & “ & 2.20 & " & " & 5 & $"$ & 45 & " \\
\hline Aver. & 44 & $"$ & $\mathrm{I} .8 \mathrm{I}$ & $"$ & & 5 & ، & $\overline{35}$ & " \\
\hline & 38 & " & I. 65 & “ & $n / I 00000 \mathrm{AgNO}_{3}$ & 8 & " & 30 & ، \\
\hline & $5 \mathrm{I}$ & $"$ & 2.05 & “ & $\because \quad \because$ & 9 & $“$ & 20 & ، \\
\hline & $5 \mathrm{I}$ & " & 2.10 & " & “ & 9 & “ & 5 & " \\
\hline Aver. & $\overline{47}$ & “ & I.93 & $"$ & & 8 & “ & $\overline{58}$ & ". \\
\hline & $5 I$ & “ & I.95 & “ & $n /$ I00000 $\mathrm{Ag}_{2} \mathrm{SO}_{4}$ & 9 & " & 25 & " \\
\hline & 38 & “ & I. 55 & “ & 164 & 8 & s" & 45 & “ \\
\hline & 64 & $"$ & 2.85 & “ & ، & 9 & " & 25 & “" \\
\hline Aver. & 51 & " & $2.1 \mathrm{I}$ & $"$ & & 9 & " & I I & " \\
\hline
\end{tabular}

A comparison of the results of Table II. with the corresponding ones of Table I. shows that shiners succumb nuch more readily to the action of acid solutions than do rock-bass. It is well to note in this connection that both species live about the same length of time in distilled water - see Tables I. and II. - as do also brook-trout and percli - see Tables II. and IV. The shiner is a much softer fish than the bass. The membranes of the former are much more delicate and more readily attacked by acids, which is evident from the more profuse hemorrhage from the gills in corresponding solutions. 
Table II. shows that in $n /$ Ioo solutions, death occurred five seconds sooner in $\mathrm{HNO}_{3}$ than in $\mathrm{HCl}$ and $\mathrm{H}_{2} \mathrm{SO}_{4}$, the time being twenty seconds for each of the latter acids. It will be observed, however, that the specimen placed in $\mathrm{HNO}_{3}$ was only one-third as heavy as that introduced into $\mathrm{HCl}$. More tests with $n /$ IOO acids were not made because the number of fishes at hand was limited, and because death occurred so quickly as to make errors in estimating the time relatively great. The results in the case of the solutions weaker than $n /$ ioo are much more reliable. It will be noted that in $n / 25 \mathrm{O}$ solution of $\mathrm{HNO}_{3}$, shiner survives for 83 seconds, while in $n / 250 \mathrm{HCl}$ death occurs after 55 seconds, and this in spite of the fact that the specimens in $\mathrm{HNO}_{3}$ were not so large as those placed in the $\mathrm{HCl}$. Again, in $n / 250 \mathrm{H}_{2} \mathrm{SO}_{4}$ shiner survives for $\mathrm{I} 28$ seconds; to be sure the specimens tused in this acid were somewhat lighter and consequently probably somewhat less resistant than those used in $\mathrm{HCl}$ and $\mathrm{HNO}_{3}$. In $n / 500$ solutions $\mathrm{HCl}$ and $\mathrm{HNO}_{3}$ show about the same toxic power, the time being 140 and ${ }_{4} 46^{3}$ seconds respectively; $n / 500 \mathrm{H}_{2} \mathrm{SO}_{4}$, however, permits the fish to live for 245 seconds. In the $n /$ I000 solutions $\mathrm{HCl}$ and $\mathrm{HNO}_{3}$ again show the same toxic action, while $\mathrm{H}_{2} \mathrm{SO}_{4}$ still lags behind, the time for the latter being 370 seconds, while for the former two acids it is 280 and 260 seconds, respectively. Here again, then, as in the case of rock-bass, $\mathrm{HCl}$ and $\mathrm{HNO}_{3}$ exert approximately the same toxic effect; but $\mathrm{H}_{2} \mathrm{SO}_{4}$ is relatively mucl weaker in its action than in the previous case. Indeed the action of $\mathrm{H}_{2} \mathrm{SO}_{4}$ is so weak as compared with that of $\mathrm{HCl}$ and $\mathrm{HNO}_{3}$, that the assumption that the effect is due to hydrogen ions cannot be held here, for in dilute solutions like $n / 1000 \mathrm{HCl}$ and $\mathrm{HNO}_{3}$ are practically completely dissociated (if the theory of electrolytic dissociation be assumed) and the same is almost true of $\mathrm{H}_{2} \mathrm{SO}_{4}-$ compare the results of Kollrausch's conductivity measurements. ${ }^{\mathrm{I}}$

It will be observed that a $n / 100 \mathrm{KOH}$ solution is less destructive than a $n /$ Ioo of the strong mineral acids, but a $n / 500$ $\mathrm{KOH}$ solution is much more toxic than $n / 500$ acid, the fish sur-

${ }^{1}$ See Ostwald. Lehrbuch d. Allgen. Chemie, II, , $2^{\text {te }}$ Auflage. 
viving only 76 seconds in the former, but I 40 seconds in the latter. In the $n /$ rooo KOH again, the specimens survived but I 38 seconds, while in the equivalent solution of $\mathrm{HCl}$ they live double that length of time. On the basis of the dissociation theory the action of $\mathrm{KOH}$ must be ascribed to the $\mathrm{OH}$ ions. The effect that the $\mathrm{K}$ ions wotnld have at these dilutions is exceedingly slight, as any one may easily assure himself by placing a fish in a $\mathrm{KCl}$ solution of equivalent strength. Again, $\mathrm{KOH}$ solutious must be assumed to be fully as highly dissociated as $\mathrm{HCl}$ solutions of equivalent strength. 'It is, therefore, difficult to explain, on the basis of the dissociation theory, why $\mathrm{KOH}$ solutions change their toxicity so slightly on dilution as compared with equivalent $\mathrm{HCl}$ solutions. Death is no doubt caused by the caustic action of the potash on the membranes of the fish, especially on the membranes of the gills. Hemorrhages occurred in the $n /$ Io and $n /$ Ioo solutions, the blood being rapidly coagulated in thick clots. The fish acquired a glossy appearance, simulating in some cases a metallic luster. A fluid of the consistency of glycerine dropped from the dead fish when lifted from the solution. The eyes seemed not affected. The month was partly open; the gill chambers were relaxed; and the gills were strongly attacked. Bleeding occurred in $n / 500$ and $n /$ rooo solutions; it was slight, however, and the blood was soon coagtulated.

In a $n / 10 \mathrm{NaCl}$ solution; a shiner survives for several hours. It will be seen from the the table that $n / \mathrm{I}, n / 2$, and $n / 4$ solutions were used. A $n / \mathrm{I}$ solution of $\mathrm{NaCl}$ kills the shiner in about the same time that a $n / 25 \mathrm{O}$ solution of $\mathrm{HNO}_{3}$ does. A $n / 2$ solution of $\mathrm{NaCl}$ is, however, considerably less toxic than a $n / 500$ $\mathrm{HNO}_{3}$ solution, while $n / 4 \mathrm{NaCl}$ is less hamful than $n / 2000$ $\mathrm{HNO}_{3}$. Shiners killed in $\mathrm{NaCl}$ solutions remain normal in appearance. Hemorrhages do not occur; the gills retain their normal appearance; the mouth is closed, but not tightly.

The tremendons toxic power of the solutions of the nitrate and sulphate of silver as compared with the other solutions tested is at once evident from the table. It further appears that the sulphate and nitrate of silver lave about the same toxic action; 
that is, of course, readily ascribed to that which they have in common, namely, their silver content. In terms of the dissociation theory it is the $\mathrm{Ag}$ ion that here exerts the toxic effect, since these salts are both practically completely dissociated at these high dilutions (see table) and since the anions are practically harmless at such high dilutions. Fishes killed in these silver solutions assumed a pinkish hue. The mouth was closed. Bleeding did not occur. The gill chambers were tightly closed and the gills were corroded, being of a dirty gray appearanre. In solutions stronger than $n /$ IOoo the specimens were killed very quickly, so that no very accurate measurements of the time that they survive could be made.

Table III. now follows, giving the results obtained with brook-tront. It will be observed that a larger variety of solutions was tested with this species.

\section{TABLE III}

Brook-trout (salvelinus fontinalis)

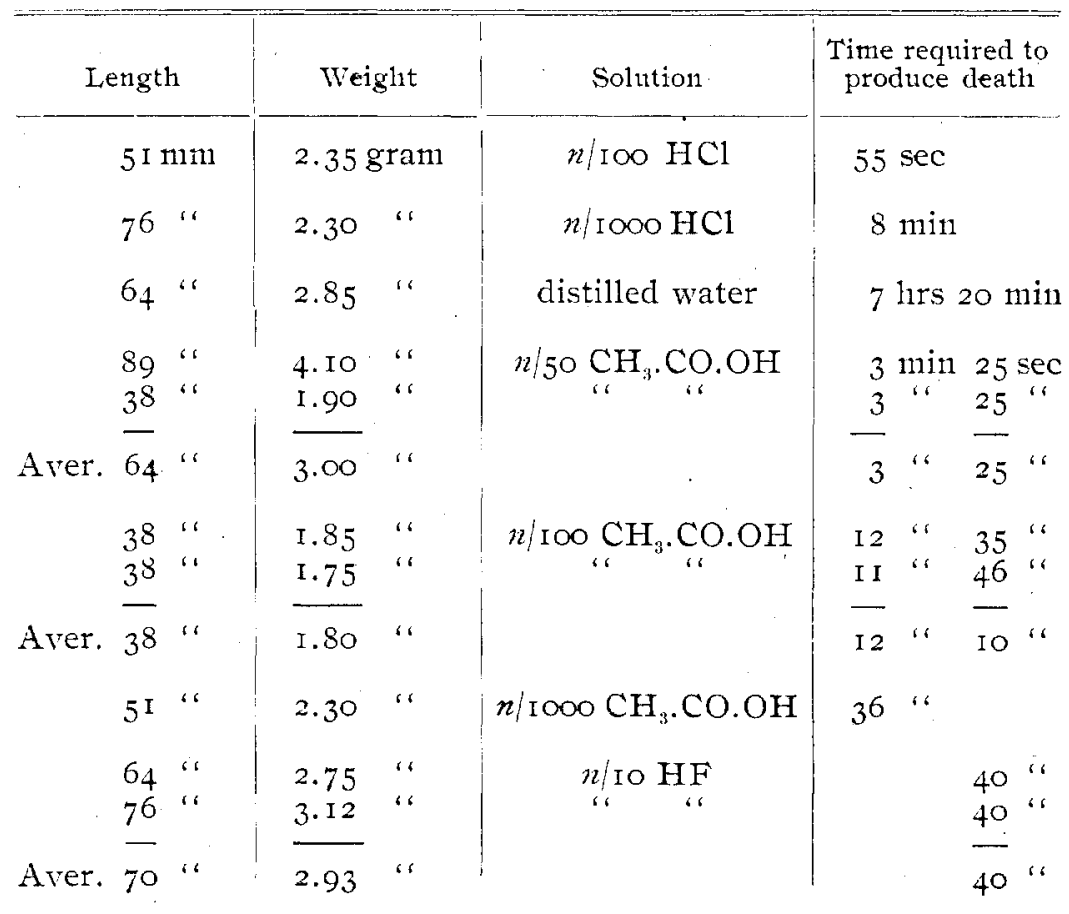




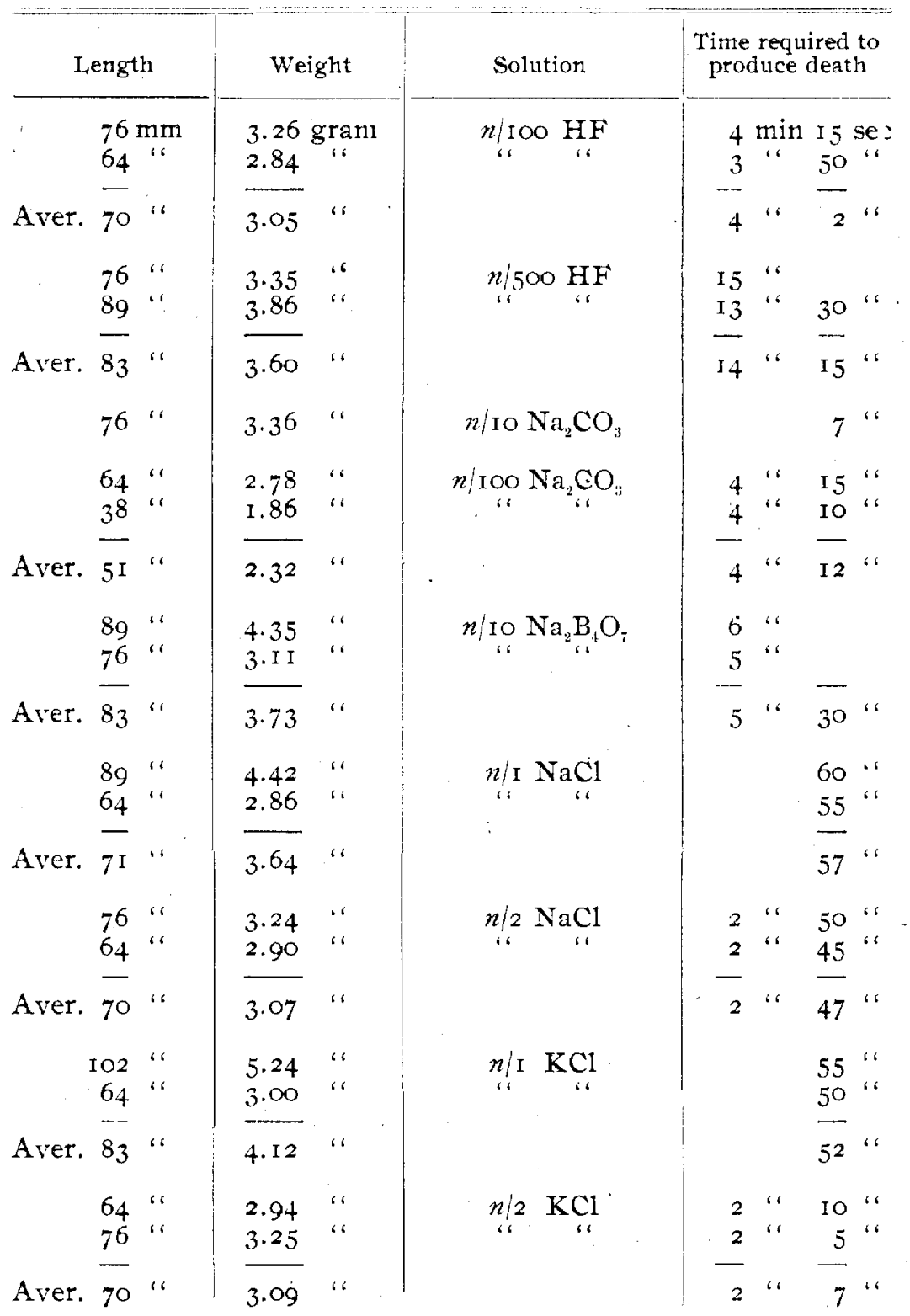




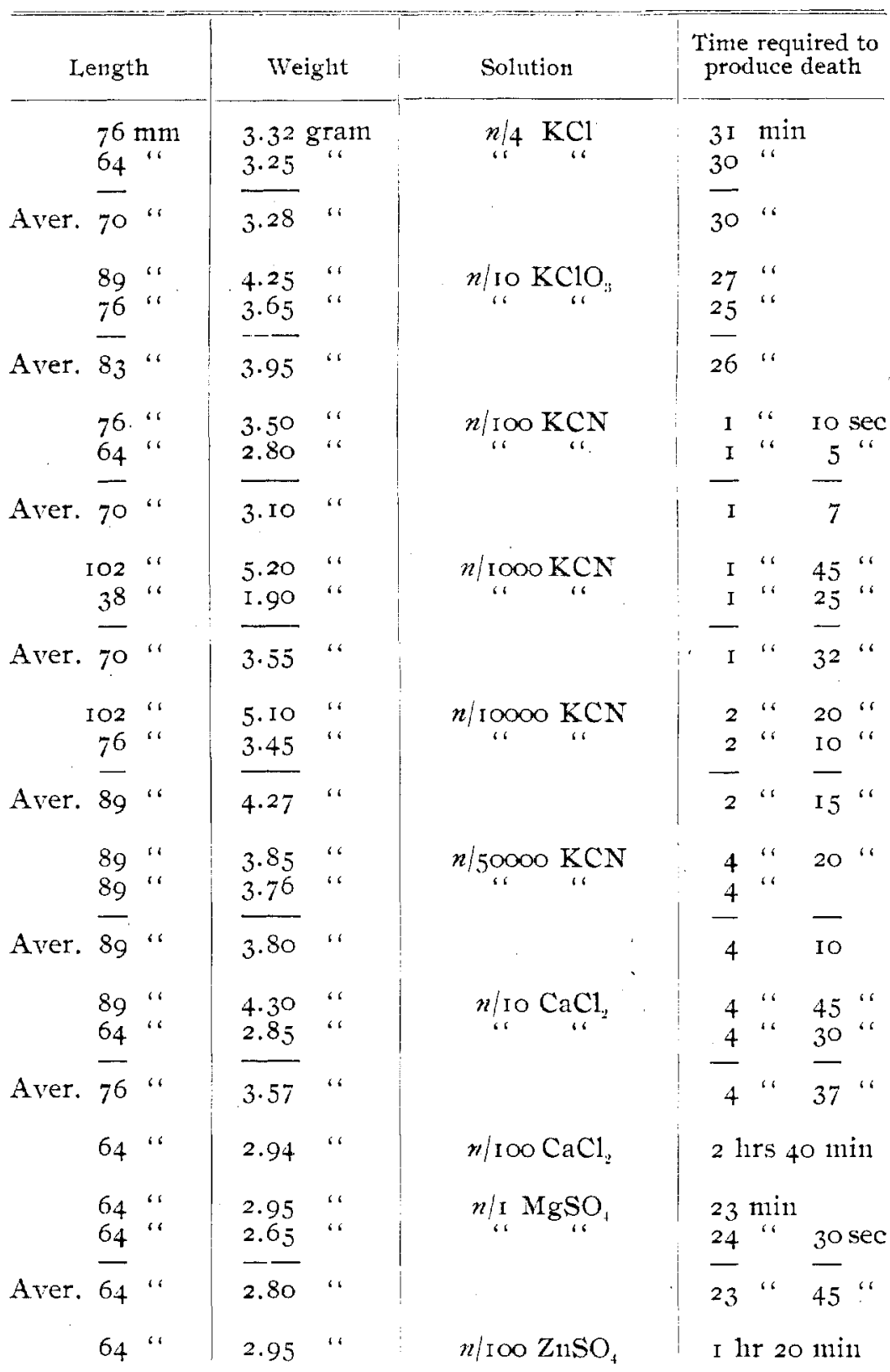




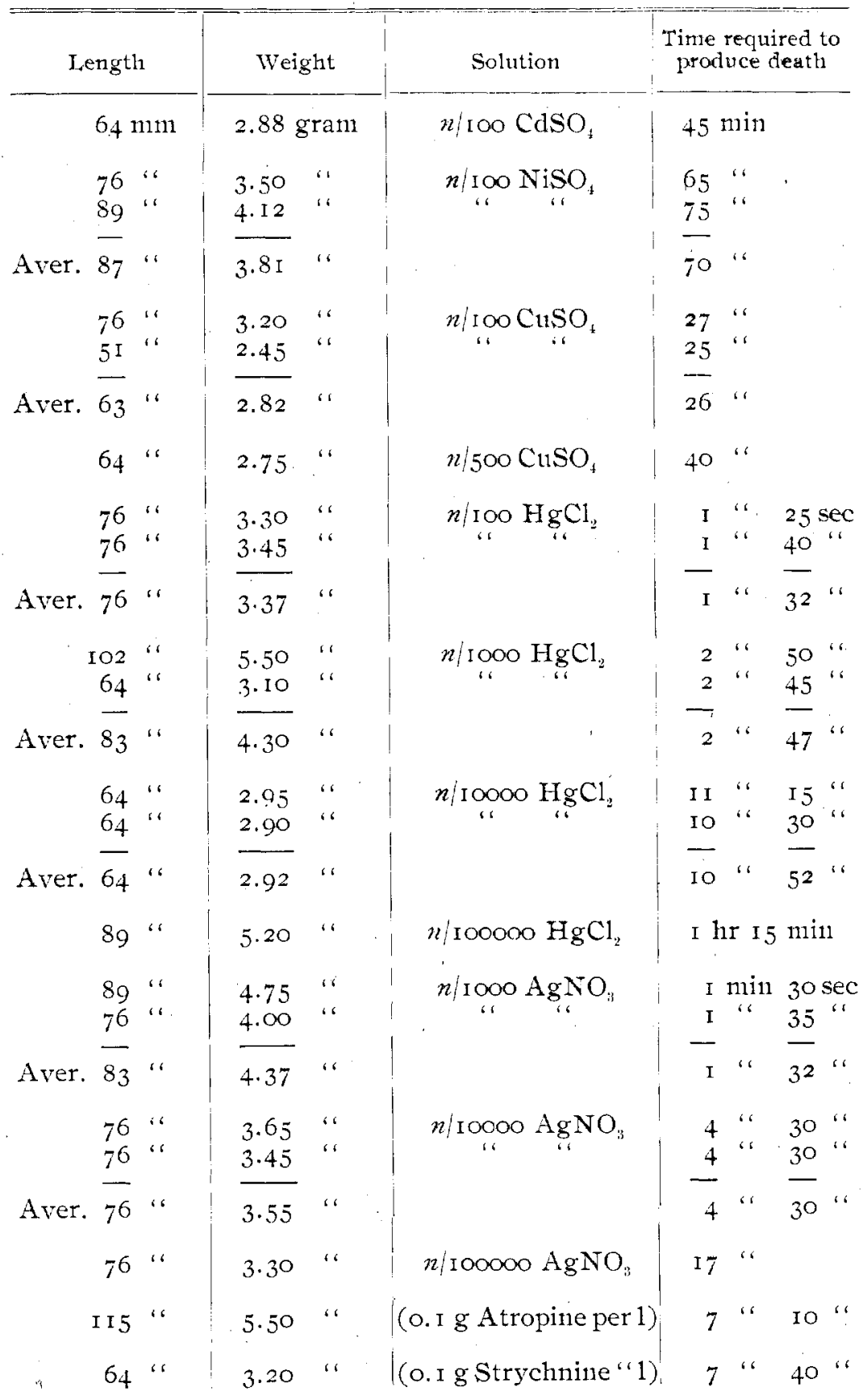


The results in Table III. show that brook-trout survives longer in $n /$ roo and $n /$ IO0 $\mathrm{HCl}$ solutions than does shiner, but not as long as rock-bass. The results obtained with acetic acid are interesting. . They show that $n / 50$ acetic acid solution is much more toxic in character than $n /$ rooo $\mathrm{HCl}$. Inasmuch as the electrical conductivity of solutions of acetic acid shows that $n / 50$ acetic acid is electrolytically dissociated to the extent of about 2.9 percent, such a solution contains I gram $\mathrm{H}$ ions in 1724 liters. Now if toxicity depended solely upon the $\mathrm{H}$ ions in the case of this acid, $n / 50$ acetic acid should have the same effect as a $n / \mathrm{I} 724 \mathrm{HCl}$ solution; as a matter of fact, it has a much greater toxic effect than $n /$ Iooo $\mathrm{HCl}$, as already stated. The general appearance of fishes killed with acetic acid is about the same as that of those clestroyed with mineral acids. No hemorrhage was observed. The gills were dark brown, having a dirty gray fringe.

Fislies killed in $\mathrm{HF}$ solutions also had abont the same appearance as those that were acted upon by the other acids mentioned. Bleeding did not occur. The results in Table III. show that $\mathrm{HF}$ solutions are not nearly as toxic in their action as are solutions of $\mathrm{HCl}$. It was further observed that a fish 64 $\mathrm{mm}$ long lived over an hour in $n / \mathrm{I00O} \mathrm{HF}$ solution, which clearly shows the relatively weak poisonous character of this acid. It is of interest to note in this connection that Paul and Krönig ${ }^{2}$ found that in stronger solutions $H F$ is a much more powerful disinfectant than the other mineral acids.

Sodium carbonate solutions have about the same destructive power as $H F$ solutions of equivalent strength, which is evident from a comparison of the figures in the last column of Table III. for $n /$ Ion solutions of these substances. A fish killed in $\mathrm{Na}_{2} \mathrm{CO}_{3}$ solutions retains in general its normal appearance. The month and gill chambers are closed, though not tightly, and the gills have a maroon color. Just before the fish succumbs to the action of the solution the gill chambers and month open wider, the gills separate somewhat, and all finally becomes rigid.

1 Zeit. phys. Chem. 2I, 414 (1896). 
The same general behavior was also noted in the case of solutions of $\mathrm{ZnSO}_{4}, \mathrm{CdSO}_{4}, \mathrm{NiSO}_{4}$, and $\mathrm{CuSO}_{4}$.

From Table III. it appears that a $n /$ Io borax solution is somewhat less toxic than $n / 100 \mathrm{Na}_{2} \mathrm{CO}_{3}$. The fishes destroyed by the borax solution have about the same appearance as those acted upon by dilute solutions of sodiun carbonate.

The data obtained with common salt solntions show that brook-tront are more strongly affected by brine than are shiners. Further, the table shows that $\mathrm{KCl}$ solutions are slightly more destructive than are $\mathrm{NaCl}$ solutions of equivalent strength. Brook-trout killed in $\mathrm{KCl}$ or $\mathrm{NaCl}$ solutions retain their normal appearance. The gills are blood red, the mouth and gill chanbers are closed; and no hemorrhage occurs.

A $n / 10 \mathrm{KClO}_{3}$ solution exercises a slightly greater destructive effect than a $n / 4 \mathrm{KCl}$ solution. The post-mortem appearances of the specimens are about the same as those in the case of $\mathrm{KCl}$ solutions.

The extremely toxic action of $\mathrm{KCN}$ solutions is evident from the table. Here as in the case of the action of $\mathrm{KOH}$ on shiners (Table II.), the lengtl of time that the fish survives increases relatively slightly with the dilution of the solution. Table III. shows that $n / 50000 \mathrm{KCN}$ is more destructive than $n / I 0000 \mathrm{AgNO}_{3}$. In the case of Lupinus albus it was found that $\mathrm{AgNO}_{3}$ is much more poisonous than $\mathrm{KCN}$. Brook-tront killed in $\mathrm{KCN}^{3} \mathrm{~N}$ solutions have a normal appearance, except that they acquire a somewhat darker luster.

Calcium chloride solutions are more harmful than potassium chloride solutions, as is evident from Table III. The general post-mortem appearances of the specimens are the same as those of the $\mathrm{KCl}$ solutions, except that the gills have slightly gray edges. In $n / \mathrm{I} \mathrm{CaCl}_{2}$ solutions, brook-tront die in from is to 45 seconds.

According to Table III., it takes over 23 minutes for a brook-tront to succumb in $n / \mathrm{x} \mathrm{MgSO}_{4}$ solution, from which fact the relatively slight destructive action of this salt is evident. The post-nortem appearances are nearly the same as in the case of $\mathrm{NaCl}$. 
Zinc sulphate solutions are not very toxic, as is evident from the fact that a trout lived for over an hour in a a $n /$ roo solution. The mouth of the dead fish was wide open; the gill chambers were relaxed; the body was rather limp and had more of a metallic luster; the gills were of a grayish color. The table further indicates that $\mathrm{CdSO}_{4}$ is more poisonous than $\mathrm{NiSO}_{4}$, and that $\mathrm{CuSO}_{4}$ is more powerfut in its destructive effects than either of these. A trout killed in $\mathrm{CdSO}_{4}$ solution had purplish gill chambers; its mouth was wide open; its gills were grayish ; its body was flexible and had a somewhat metallic luster. Tront that succumbed in $\mathrm{NiSO}_{4}$ solution had maroon gills, partly opened months, relaxed gill chambers. Their bodies became darker after a time. Specimens killed by $\mathrm{CuSO}_{4}$ solutions had wide open mouths and gills with a slightly bluish tinge. Their bodies also became darker after a time as in the case of the victims of the $\mathrm{NiSO}_{4}$ solutions.

Solutions of $\mathrm{AgNO}_{3}$ are more toxic than equivalent solutions of $\mathrm{HgCl}_{2}$. The same was fonnd to be true in the case of Lupinus albus. While $\mathrm{HgCl}_{2}$ is less active than $\mathrm{AgNO}_{3}$, it nevertheless is extremely destructive as the results show. Trout killed in $\mathrm{HgCl}_{2}$ solutions acquired a grayish metallic luster and were surrounded by a translucent coating. The mouths and gill chambers were wide open. As in the case of the silver salts, $\mathrm{HgCl}_{2}$ destroys the protective tissues of the gills. Hemorrhage does not result.

To enable those that may desire to do so to make a comparison of the toxic action of the various solutions with the effect of solutions of the alkaloids, two tests were made, one with atropine and the other with strychnine. The strength of the solntions was o.or percent in each case. It will be observed that their toxicity is not very different. The trout swam about violently in the solutions, especially in the strychnine solution. After death, the bodies of the fish became rigid and the mouths and gill chambers were wide open. The gills were blood-red. No hemorrhage was observed.

The results of the lew experiments that were performed with perch are given in Table IV. 
TABLE IV

Perch (perca flavescens)

\begin{tabular}{|c|c|c|c|}
\hline Length & Weight & Solution & $\begin{array}{l}\text { Time required to } \\
\text { produce death }\end{array}$ \\
\hline I $27 \mathrm{~mm}$ & 26 grams & $n / 1000 \mathrm{HCl}$ & $55 \mathrm{~min}$ \\
\hline "6 & 27.5 & $n / 1000 \mathrm{HNO}_{3}$ & $50 \cdots$ \\
\hline 611 & 26 & $n / 1000 \mathrm{H}_{2} \mathrm{SO}_{4}$ & I hr $40 \mathrm{~min}$ \\
\hline " " & $32.5 \cdots$ & $n / 2000 \mathrm{HNO}_{i}$ & $6 " 40 "$ \\
\hline " & 32.5 & distilled water & $7 " 40 "$ \\
\hline
\end{tabular}

It will be noticed that the perch were much heavier than the specimens previously used and that they survived much longer in the $n / 1000$ solutions of the strong mineral acids than did the fish in the other cases. Here, too, $\mathrm{HNO}_{3}$ and $\mathrm{HCl}$ have approximately the same toxic power, while $\mathrm{H}_{2} \mathrm{SO}_{4}$ is apparently only one-half as $\epsilon$ ffective. According to the explanation that the theory of electrolytic dissociation gives of the poisonous properties of these acids, namely that their effect is due to $\mathrm{H}$ ions, $\mathrm{H}_{2} \mathrm{SO}$ in $n /$ IOOO solutions ought to have nearly the same effect as the equivalent solutions of $\mathrm{HCl}$ and $\mathrm{HNO}_{3}$.

Laboratory of Physical Chemistry,

University of Wisconsin, Madison. 